Article

\title{
The European Central Bank and the German Constitutional Court: Police Patrols and Fire Alarms
}

\author{
Clément Fontan ${ }^{1, *}$ and David Howarth ${ }^{2}$ \\ ${ }^{1}$ Institute of Political Science Louvain-Europe, Catholic University of Louvain, 1000 Bruxelles, Belgium; \\ E-Mail: clement.fontan@uclouvain.be \\ 2 Department of Social Sciences, Institute of Political Science, University of Luxembourg, 4366 Esch-sur-Alzette, \\ Luxembourg; E-Mail: david.howarth@uni.lu \\ * Corresponding author
}

Submitted: 1 December 2020 | Accepted: 26 January 2021 | Published: 27 May 2021

\begin{abstract}
In May 2020, a ruling of the German Federal Constitutional Court (FCC) questioned the legality of the Bundesbank's participation in the European Central Bank's (ECB's) Public Sector Purchase Programme. Applying elements of a principal-agent analysis, this article analyses how the FCC ruling presents us with a new understanding of the relationship between the ECB, other EU institutions and Eurozone member states. Existing principal-agent analyses of the ECB focus upon its relations with other EU-level institutions and point to the limited ex ante control mechanisms and efforts to reinforce ex post control mechanisms - notably European Parliament oversight. The FCC ruling and the ECB's reaction demonstrate the relative importance of national level controls over the ECB agent. This article understands the role of private plaintiffs in Germany as a form of 'fire alarm' on ECB policymaking against the background of weak ex post controls at the EU-level.
\end{abstract}

\section{Keywords}

accountability; Bundesbank; Bundestag; Court of Justice of the European Union; European Central Bank; European Parliament; German Federal Constitutional Court; monetary policy; ordo-liberalism; principal-agent analysis

\section{Issue}

This article is part of the issue "Reforming the Institutions of Eurozone Governance" edited by Anna-Lena Högenauer (University of Luxembourg), David Howarth (University of Luxembourg) and Moritz Rehm (University of Luxembourg).

(C) 2021 by the authors; licensee Cogitatio (Lisbon, Portugal). This article is licensed under a Creative Commons Attribution 4.0 International License (CC BY).

\section{Introduction}

On 5 May 2020, the German Federal Constitutional Court (FCC) presented a ruling (Weiss and others, 2020) that put into question the legality of the Bundesbank's participation in the European Central Bank's (ECB's) Public Sector Purchase Programme (PSPP). The ruling created an intense backlash at the EU-level for its potential economic, legal and political implications. In the midst of an unprecedented crisis created by the Covid-19 pandemic, the FCC's ruling threatened to undermine, if not eliminate altogether, the most important macroeconomic response to the crisis implemented by the ECB at the EU-level-the Pandemic Emergency Purchase
Programme (PEPP). The FCC's ruling is the latest episode of a long-term jurisdictional struggle between the German Constitutional Court and the EU Court of Justice (CJEU) over the operation of the ECB in particular, and EU integration more generally (Davies, 2012; see also Table 1).

Indeed, a group of German private plaintiffs has challenged before the FCC all the ECB's asset purchase programmes launched since 2010 (Arnold \& Chazan, 2020a; De Cabanes \& Fontan, 2019). Yet, judging the legality of ECB monetary policy falls primarily within the CJEU's jurisdiction. Hence, the FCC has passed on the cases to the CJEU through the preliminary ruling procedure but reserved the right to review the latter's 
decisions. For example, when the European Court ruled against the complaint introduced by Peter Gauweilera former Bundestag member of the Bavarian Christian Social Union party-against the Outright Monetary Transactions (OMT) in 2016, the FCC judges recognized the primacy of the CJEU jurisdiction but they also expressed their dissatisfaction with the content and form of the CJEU ruling.

On 5 May 2020, the FCC judges found that the CJEU's Weiss and Others $(2018,2020)$ ruling was ultra vires as it failed to provide an adequate assessment of the proportionality of the ECB's PSPP. The FCC required the ECB to justify its programme to the German government and parliament within three months. More specifically, the FCC required the ECB to demonstrate that the economic impact of its bond purchases was proportionate to the objectives set out in the EU treaties-the Maastricht Treaty and the Lisbon Treaty (TFEU). Following the FCC ruling, if the German federal government and Bundestag (the lower house of the German federal parliament) had reached the conclusion that the ECB was exceeding its prerogatives, then the Bundesbank would have been obliged to withdraw from the PSPP and all German government bonds purchased by the Bundesbank under the PSPP would have had to be sold (Fazzini \& Urbani, 2020). The FCC ruling does not disentangle the responsibility of the two institutions: "The Federal Government and the Bundestag are required to take steps seeking to ensure that the European Central Bank conducts a proportionality assessment" (Weiss and Others, 2020).

The ECB initially announced that it was subject exclusively to the jurisdiction of the CJEU, which had found the PSPP legal (Mersch, 2020). Several Governing Council members even argued that the ECB should not respond to the FCC ruling as it would create a legal precedent that could undermine the efficiency of its policies (Arnold, 2020). The CJEU and the European Commission also underlined that the FCC ruling was not in line with the constitutional order in the EU (Von der Leyen, 2020). However, during the two next months, the ECB deployed considerable efforts to prepare a detailed answer to the FCC's ruling. This answer demonstrates that the ECB was cautious to avoid a potential political and economic crisis linked with the ruling from German judges.

Against this background, the aim of this article is to analyse the politics of this new relationship between the ECB and the FCC, and between the ECB and national level fire alarms more generally. We thus seek to answer the following research question: How should we best understand the relationship between the operationally independent ECB and the FCC? Legal analysis provides important insights as to the impact of this issue on the EU constitutional order but limited guidance to explain the ECB's response to the FCC ("Preliminary References to the Court of Justice," 2015; "The German Federal Constitutional Court's PSPP Judgment," 2020; "The OMT Decision," 2014). From a political science perspective, the relationship between two independent institutions operating at the national and supranational level is a good vantage point to analyse power struggles and legitimacy concerns within Economic and Monetary Union (EMU). In particular, this conflict begs the question of who controls the ECB's monetary policy, knowing that the ECB has been granted an unprecedented level of independence from other institutions in its polity (Howarth \& Loedel, 2005; Quaglia, 2008).

Applying elements of a principal-agent analysis, we answer this research question by arguing that the FCC ruling was a national level fire alarm-an ex post control on ECB monetary policy - which the ECB was unable to ignore politically. More precisely, we argue that the inability of police patrols and fire alarms to force the ECB to justify its nonconventional monetary policy at the EU level was conducive to the emergence of ex post controls at the national level. In other words, the perceived ineffectiveness of the control mechanisms over the ECB's monetary policy at the EU level increased efforts to hold the ECB to account at the national level.

Existing principal-agent analyses on these questions focus upon the EU-level and underline the considerable autonomy assigned to the bank by its member state principals, the limited ex ante control mechanisms (Elgie, 2002) and efforts to reinforce ex post control mechanisms-notably by improving the oversight of the ECB's monetary policy by the European Parliament (Jabko, 2003). The FCC ruling presents us with a new understanding of the application of a principal-agent analysis to the operation of the ECB agent and its relationship with its member state principals for two reasons. First, the control mechanisms were managed at the national level. Second, the control mechanisms included private plaintiffs. Conversely, studies of the relationship between national governments and parliaments and the ECB focus upon the 'politicisation' of monetary policy usually for domestic political ends (Dyson \& Marcussen, 2009; Tesche, 2019). This national-level politicisation has not yet been examined in terms of the focus of the principal-agent analysis upon ex post controls on ECB monetary policy. However, the recent ruling of the FCC demonstrates the need to extend the principal-agent analysis to the national level. We also analyse how ex post mechanisms play out in the case of the ECB's other (non-monetary) policies-notably, banking supervision and the ECB's participation in the Troika-in order to highlight the specificities of these mechanisms when they apply to monetary policy.

The next section in this article examines the relevance of principal-agent analysis to the operations of the ECB and its relations with other EU institutions and national-level bodies. The third section examines the weak ex post control mechanisms at the EU and national levels, prior to focusing on the significance of legal challenges as fire alarms brought by private plaintiffs at the national level. The conclusion considers the likelihood of ongoing legal challenges at the national level. 


\section{Who Can Control the Independent ECB?}

\subsection{The Principal-Agent Framework and the ECB}

This study employs elements of the principal-agent framework to analyze the surveillance relationships between, on the one hand, EU institutions, member states bodies and individuals and, on the other hand, the ECB. In applying elements of the principal-agent analysis, we recognize the potential validity of the argument that, with regard to the ECB's monetary policy, it is more appropriate to understand the ECB as a 'trustee' of national governments rather than as an 'agent' because monetary policy was delegated to overcome problems arising from time inconsistency (see Delreux \& Adriaensen, 2017; Majone, 2001). In particular, the principal-agent framework cannot determine whether the ECB's policies are in line with the principal's preferences because the ECB's objectives were left deliberately vague in the treaty (Elgie, 2002). If this vagueness is interpreted as a commitment to ensure a high level of ECB autonomy, the risk of agency shirking or slippage is highly unlikely because the central bankers define their objectives themselves. By contrast, if this vagueness is interpreted as a mechanism to allow the principals' preferences to evolve, agency shirking or slippage can occur, but the time inconsistency problem remains.

Nonetheless, even as a trustee of governments, the issue of adequate scrutiny of ECB monetary policy remains and the concepts of ex post police patrols and fire alarms are analytically useful (Pollack, 1997). In a principal-agent approach, principals delegate authority, administrative responsibility and tasks to agents because of their organisational capacities and technical competence. Tensions exist because agents often have their own agendas, organisational imperatives, and turf issues that may conflict with those of their principals. Efforts by agents to seek autonomy from hierarchical control contribute to agency loss or slack in the forms of shirking and slippage. Shirking arises from the agent's preference to not fully implement the principals' preferences. Slippage arises when the agent develops distinct preferences from those of the principal as set in the terms of delegation. Slippage can be agent-induced or structure-induced. The latter occurs when the agent's use of its discretion derives neither from its own interests nor those of the principal but as a consequence of the environment in which the principal implements its tasks (Chang, 2020; Delreux \& Adriaensen, 2017). Agency slack therefore rests on a continuum (Hawkins, Lake, Nielson, \& Tierney, 2006; Heldt, 2017). Agents benefit throughout these relationships from the advantage of privileged information regarding their own preferences, capabilities, and efforts at implementing delegated tasks. This asymmetrical information limits principals from fully understanding and evaluating the activities of their agents (Kiewiet \& McCubbins, 1991; Miller, 2005).
Principals attempt to address this information asymmetry and control the risk of agency shirking and slippage through ex post controls, known also as oversight procedures. These ex post controls are conventionally divided into 'police patrols' and 'fire alarms' (Kiewiet \& McCubbins, 1991). 'Police patrols' consist of an active surveillance of a sample of the agent's behaviour by the principal with the aim of detecting any of their non-compliance with the principal's policy preferences. These include public hearings, studies, field observations and examinations of regular agent reports (Pollack, 1997). 'Fire alarms' are the principal's indirect ex post controls because in its monitoring of the agents' activities, the principal relies on the support of third parties. 'Fire alarms' are less costly but at the same time, they are also less centralised and tend to be more superficial than 'police patrols.' Classic principal-agent analysis expresses a clear preference for 'fire alarm' monitoring over police patrols (McCubbins \& Schwartz, 1984).

All of these dynamics are present in the EU and more specifically with regard to the operation of the ECB, an agent that was granted considerable political and operational independence from both member state government principals and other EU institutions (Howarth \& Loedel, 2005). Member state governments, operating as a collective principal (Chang, 2020; Dehousse, 2008) set the terms of delegation for the ECB agent in the Maastricht Treaty. The ECB is characterized by a narrow mandate, centred on the overarching objective of price stability, and a very high level of independence: It has the autonomy to define its policy objectives and instruments. The only meaningful operational restriction enshrined within the ECB mandate is the prohibition of the monetary financing of government debt. This prohibition derived from the influence of the Bundesbank on the ECB template (McNamara, 1998).

In the principal-agent framework, the modification of the mandate of the agent by the principals is the strongest form of ex ante control. Indeed, if principals notice agent slippage, they can modify the agent's objectives as well as its degree of autonomy. Yet, this ex ante control is hardly applicable in the case of the ECB because the modification of its mandate requires Treaty change and, thus unanimous agreement among EU member states (Jabko, 2009). Member states can also exert another form of ex ante control when they appoint the ECB's executive board. Yet, since member states have distinct, and at times opposed, economic preferences, the politics of ECB appointment follow an intergovernmental logic where the nationality of the candidate matters more than policy ideas (Fontan, 2016). Consequently, a change in ECB personnel is more informed by the outcome of power struggles between member states than by the logic of agency control. In sum, the diversity of preferences within the collective principal strongly undermines the ex ante controls over the ECB. 


\subsection{Weak Police Patrols and Fire Alarms at the EU-level}

Three institutions form the police patrols in relation to the ECB at the EU-level. First, the European Parliament monitors ECB activities. The legal basis allowing the European Parliament's surveillance of ECB activities is very weak: The TFEU only requires the ECB to present its Annual Report to the Parliament. The Parliament expanded its monitoring function with the ECB's active cooperation from 1999 onwards with the use of a number of mechanisms including reports, questions addressed directly to the ECB in letter form, and questions to the ECB Governing Council members who attend meetings of the Parliament's Economics and Finance Committee. This voluntary cooperation benefits both institutions: On the one hand, the ECB strengthens its democratic responsiveness-or at least the appearance of this responsiveness; on the other hand, the European Parliament gains a position of privileged interlocutor with the ECB despite its historical weakness on macroeconomic issues (Jabko, 2001). Yet, the lack of coercive legal tools weakens the oversight power of the Parliament. In the rare direct confrontations between the ECB and the Parliament, the latter's position was systematically dismissed by central bankers in the name of their independence. For example, the European Parliament (2014) adopted a resolution criticizing the role of the ECB in the EU Troika expert groups sent to countries benefiting from EU loans. The ECB dismissed the Parliament's criticism and continued to participate in the Troika.

Second, the EU Court of Auditors performs audits on some ECB activities. In 2018, the Court audited the ECB in its role as banking supervisor, but only partially, since the ECB would not make certain documents available during the audit. The compromise found between the two institutions was to sign a memorandum allowing the release of bank-specific data to the Court of Auditors while the latter underlined that it was 'not seeking to audit monetary policy' (Court of Auditors, 2019).

Third, the CJEU has the power to investigate ECB measures when third parties legally challenge it within a period of two months (article 263 TFEU). From a principal-agent perspective, third parties are fire alarms. At the EU-level, they include the European Commission and the European Parliament in that these institutions are not part of the multiple principals and had, at most, a secondary role in determining the original ECB mandate. Both institutions can launch legal proceedings against the ECB. However, since the start of EMU in 1999, neither the European Parliament nor the Commission have ever legally challenged the choice or design of the ECB's monetary instruments. Neither have operated as a fire alarm on ECB monetary policy. However, the European Commission has brought cases against the ECB to the CJEU on other matters including the delimitation of competences between the Commission and the ECB (Commission v. ECB, 2003).
Finally, the history of CJEU jurisprudence towards the ECB shows a marked contrast between the legal cases on monetary policy and other issues (De Cabanes \& Fontan, 2019). On the one hand, CJEU judges perform a substantive analysis on cases that are not directly related to monetary policy and sometimes rule against the ECB opinion. On the other hand, when CJEU judges have to evaluate the legality of monetary instruments, their judicial review is procedural and they are careful not to second-guess the ECB opinion (Baroncelli, 2016).

\subsection{Weak National Police Patrols}

Turning to the national level, the Eurozone member states rely on their national parliaments and courts to monitor the ECB's monetary policy. In addition to sending its annual reports to national parliaments, ECB members have appeared in front of national parliaments, albeit only as a voluntary gesture of goodwill. An analysis of Mario Draghi's visits to Eurozone national parliaments shows that these visits were more akin to ceremonial strategies for the ECB to improve its accountability rather than a true form of parliamentary control (Tesche, 2019). By contrast, national parliaments can forcefully invite ECB members to appear before national parliamentary committees on banking supervision issues (Fromage \& Ibrido, 2018). However, Gandrud and Hallerberg (2015) argue that no EU member state has achieved a significant level of parliamentary scrutiny of banking supervisionby either national bodies or the ECB-which owes in part to the commercial sensitivity of the policy area.

In sum, while the process of collecting information may produce disciplinary effects through the systematic use of surveillance techniques, the compliance of agents ultimately depends upon the application of meaningful sanctions. Yet, the structural features of macroeconomic governance in the Eurozone allowed the ECB to benefit from an unprecedented degree of institutional autonomy. The legal dispositions enshrined within the European treaties provided no procedural mechanisms to other EU institutions to exert meaningful control over the ECB's monetary policy. Moreover, the deep economic and ideological divisions among Eurozone governments weakened the possibility of such controls. Hence, police patrols at both the EU and national level on ECB monetary policy and other activities have had limited impact. Given the high level of ECB independence and the timidity of police controls, the only form of potential ex post sanction for agency slippage involved the CJEU. However, over the first two decades of EMU, the ECB had avoided CJEU legal sanction that required any significant change in monetary policy. Against this background, private plaintiffs at the national level started to challenge the CJEU by launching cases in the national legal system that, through the preliminary ruling procedure, were pushed up to the EU-level. 


\section{The Extension of De Facto National Controls over ECB Monetary Policy}

\subsection{Asset Purchase Programmes and Ordo-Liberalism}

The asset purchase programmes implemented by the ECB potentially undermine two core elements of the ECB's mandate outlined in the Maastricht Treaty: the primary focus on price stability and the prohibition of the monetary financing of government debt. Given the relatively low inflation rate over most of the past decade, the topic of price stability is less immediately relevant for those concerned with ECB slippage-although there have been several challenges to the ECB on this matter and the ECB has insisted on the neutralization of its asset purchases (see, for example, Högenauer \& Howarth, 2016). Thus, agency loss, here slippage in terms of asset purchase programmes, focuses on the extent to which these programmes involve, de facto, the monetary financing of government debt. The ECB itself has insisted that sovereign bond purchases are necessary to ensure the adequate transmission of its monetary policy throughout the Eurozone and not to fund governments per se (ECB, 2015). In line with this argumentation, the ECB Governing Council delimited the purchase of sovereign debt from different national governments in the Eurozone according to its capital key-that is, the percentage of debt purchased from national governments is determined by the percentage of capital that they have contributed to the ECB. While, de facto, the ECB is engaged in the purchase of sovereign debt, it must demonstrate that these purchases are proportionate to its policy objective-that is, that their benefits outweigh their potential costs (Schnabel, 2020).

From a macroeconomic perspective, this evaluation is rather straightforward. Because sovereign debt forms the bedrock of modern financial markets, its stabilization is necessary to prevent the aggravation of financial crises (Gabor \& Ban, 2016). From this perspective, the lines between monetary and fiscal policies are necessarily blurred. However, beliefs on monetary policy and central banking arrangements vary. In Germany, these beliefs are still heavily influenced by ordo-liberalism, an economic doctrine that advocates the strict separation between fiscal and monetary policies and a prioritisation of price stability over other monetary policy objectives as necessary components of a democratic legal order (Young, 2014). Other creditor countries in the Eurozone, such as the Netherlands and Finland, share these monetary preferences, although the salience of monetary issues is lower than in Germany (Frieden \& Walter, 2017; Nedergaard, 2020).

In fact, since 2010, the strongest expressions of concern regarding ECB asset purchases came from German politicians and officials at the national level (see also Rehm, 2021). For example, Wolfgang Schäuble, the former German Finance Minister, blamed ECB unconventional monetary policy for the rise of the far-right party, Alternative Für Deutschland (Wagstyl \& Jones, 2016). A small number of national central bank leaders, notably the Bundesbank President and Governing Council members have publicly opposed ECB asset purchases (Howarth, 2012). Members of a range of national parliaments have also expressed concern and criticismnotably in Germany and the Netherlands ("Dutch parliament," 2019). Högenauer (2019) shows how ECB monetary policy became politicized in the Bundestag since the start of the sovereign debt crisis. While it is highly unlikely that this criticism forced any real change to ECB monetary policy-given ECB independence and the diversity of views in Eurozone countries-it forced the ECB to respond principally in terms of increasing outreach and communication effort to explain its monetary policy (Tesche, 2019). Draghi visited the Bundestag twice during his term as president and a number of other national parliaments once.

\subsection{National Courts as Fire Alarms}

The potentially most effective fire alarm to challenge ECB monetary policy involves judicial and administrative reviews. Judicial review by the CJEU is allowed by TFEU articles 263 and 277, while national courts can also engage in judicial review but-through the preliminary ruling procedure (article 267 TFEU)-are expected to push the cases up to the CJEU. There is also administrative review by the ECB's Administrative Board of Review and by national competent authorities on the ECB's role in banking supervision. However, with regard to monetary policy, this review has not been used.

To date, there have been numerous legal cases brought by private plaintiffs against the ECB that national courts have referred up to the CJEU. Most of these cases have focused on the ECB's role in banking supervision (Berger, 2019). However, a number of these cases focused on the ECB's monetary policy, notably on the Greek case (Accorinti and Others v. ECB, 2014). All the legal cases brought against the ECB's asset purchase programmes were undertaken by German private plaintiffs, who followed a logic of trial and error (for a full list of cases brought against the ECB asset purchase programmes adopted since 2008 see Table 1). The first constitutional complaint brought by German plaintiffs against ECB programmes was directly filed with the FCC, which found them baseless (2BvR 987/10, 2BvR 1485/10, 2BvR 1099/10). The German plaintiffs filed their second and third complaint directly with the CJEU (T-532/11, C-102/12P, T-492/12, C-64/14P). The latter dismissed their application and indicated to the plaintiffs that they should first address their complaint to the national constitutional court, which would then refer the case to the CJEU (T-492/12, alinea 47). Following the CJEU's indication in its ruling, the German plaintiffs complained directly to the FCC, which then referred to the CJEU for all the subsequent cases. 
Table 1. Summary of the legal cases brought against ECB asset purchase programmes.

\begin{tabular}{|c|c|c|c|}
\hline Case & Plaintiff(s) & Rulings & Ruling summary \\
\hline $\begin{array}{l}\text { Securities Markets } \\
\text { Programme/constitutional } \\
\text { complaint (2010) }\end{array}$ & $\begin{array}{l}\text { Hankel, Nölling, } \\
\text { Schachtschneider, } \\
\text { Spethmann, } \\
\text { Starbatty, Gauweiler }\end{array}$ & $\begin{array}{l}\text { FCC } \\
2 \text { BvR 987/10 } \\
2 \text { BvR 1485/10 } \\
2 \text { BvR 1099/10 }\end{array}$ & $\begin{array}{l}\text { Constitutional complaints dismissed } \\
\text { because unfounded. The Securities Markets } \\
\text { Programme respects Article } 123 .\end{array}$ \\
\hline $\begin{array}{l}\text { Securities Markets } \\
\text { Programme/action for } \\
\text { annulment (2011) }\end{array}$ & Städter & $\begin{array}{l}\text { Tribunal of the EU } \\
\mathrm{T}-532 / 11\end{array}$ & $\begin{array}{l}\text { Action dismissed as manifestly inadmissible } \\
\text { as it was filed out of time. }\end{array}$ \\
\hline $\begin{array}{l}\text { Securities Markets } \\
\text { Programme/appeal (2012) }\end{array}$ & & $\begin{array}{l}\text { CJEU } \\
\text { C-102/12 P }\end{array}$ & Appeal dismissed as manifestly unfounded. \\
\hline $\begin{array}{l}\text { OMT/action for } \\
\text { annulment (2012) }\end{array}$ & $\begin{array}{l}\text { von Storch and } \\
5,216 \text { other plaintiffs } \\
\text { (Zivile Koalition) }\end{array}$ & $\begin{array}{l}\text { Tribunal of the EU } \\
\mathrm{T}-492 / 12\end{array}$ & $\begin{array}{l}\text { Action dismissed as inadmissible, as the } \\
\text { applicants were not directly concerned } \\
\text { by the contested acts. }\end{array}$ \\
\hline OMT/appeal (2014) & & $\begin{array}{l}\text { CJEU } \\
\text { C-64/14 P }\end{array}$ & Appeal dismissed as manifestly unfounded. \\
\hline $\begin{array}{l}\text { OMT/constitutional } \\
\text { complaint (2013) }\end{array}$ & $\begin{array}{l}\text { Gauweiler, Hankel, } \\
\text { Nölling, } \\
\text { Schachtschneider, } \\
\text { Starbatty, von Stein, } \\
\text { Die Linke Group at } \\
\text { the Bundestag, }\end{array}$ & $\begin{array}{l}\text { FCC } \\
2 \text { BvR }(2728 / 13- \\
2731 / 13) \\
2 \text { BvE } 13 / 13\end{array}$ & $\begin{array}{l}\text { The FCC rules that the decision to create } \\
\text { the OMT programme is in contradiction } \\
\text { with TFEU (Art. 119, } 123 \text { and } 127 \text { TFEU } \\
\text { and Art. } 17 \text { to } 24 \text { ESCB Statute). Suspension } \\
\text { of proceedings, reference for a preliminary } \\
\text { ruling to the CJEU. }\end{array}$ \\
\hline $\begin{array}{l}\text { OMT/prejudicial } \\
\text { demand (2014) }\end{array}$ & $\begin{array}{l}\text { other plaintiffs } \\
\text { (Mehr Demokratie) }\end{array}$ & $\begin{array}{l}\text { CJEU } \\
\text { C-62/14 }\end{array}$ & $\begin{array}{l}\text { Articles } 119,123 \text { and } 127 \text { of the TFEU and } \\
\text { Articles } 17 \text { to } 24 \text { of the Statute of the ESCB } \\
\text { should be interpreted as allowing the ESCB } \\
\text { to adopt the OMT programme. }\end{array}$ \\
\hline ОМт/2016 & & $\begin{array}{l}\text { FCC } \\
2 \text { BvR }(2728 / 13- \\
2731 / 13) \\
2 \text { BvE } 13 / 13\end{array}$ & $\begin{array}{l}\text { The FCC follows the CJEU ruling but points } \\
\text { out that the CJEU procedural analysis } \\
\text { is problematic. }\end{array}$ \\
\hline $\begin{array}{l}\text { PSPP/constitutional } \\
\text { complaint ( } 2015 \\
\text { and 2016) }\end{array}$ & $\begin{array}{l}\text { Weiss, Lucke, } \\
\text { Starbatty, Gauweiler, } \\
\text { von Stein, Städter, } \\
\text { Kerber and 1,700 } \\
\text { more plaintiffs }\end{array}$ & $\begin{array}{l}\text { FCC } \\
2 \text { BvR 859/15 } \\
2 \text { BvR 1651/15 } \\
2 \text { BvR 2006/15 } \\
2 \text { BvR } 980 / 16\end{array}$ & $\begin{array}{l}\text { The FCC rules that the PSPP programme } \\
\text { does not respect the TFEU (Art. } 119,123 \\
\text { and } 127 \text { TFEU and Art. } 17 \text { to } 24 \text { ESCB Statute). } \\
\text { Suspension of proceedings, reference for a } \\
\text { preliminary ruling to the CJEU. }\end{array}$ \\
\hline $\begin{array}{l}\text { PSPP/Prejudicial } \\
\text { question (2018) }\end{array}$ & & $\begin{array}{l}\text { CJEU } \\
\text { C-493/17 }\end{array}$ & The PSPP programme respects the TFEU. \\
\hline PSPP (2020) & & $\begin{array}{l}\text { FCC } \\
2 \text { BvR 859/15, } \\
2 \text { BvR 980/16, } \\
2 \text { BvR 2006/15, } \\
2 \text { BvR 1651/15 }\end{array}$ & $\begin{array}{l}\text { The FCC finds the CJEU ruling ultra vires and } \\
\text { asks to the German parliament to assess } \\
\text { whether the PSPP is proportional to the ECB } \\
\text { objectives. If not, the parliament must order } \\
\text { the Bundesbank to withdraw from the PSPP. }\end{array}$ \\
\hline
\end{tabular}

Source: Authors' own compilation based on De Cabanes and Fontan (2019).

In all these cases, the German plaintiffs complained about the legality of asset purchases in the name of ordo-liberal principles (De Cabanes \& Fontan, 2019). According to the plaintiffs, purchases of sovereign debt belonged to the realm of economic policy rather than monetary policy and disrespected the 'no bail out' clause of the TFEU (Articles 119 and 127). These concerns related directly to the strict separation between fis- cal and monetary policy in the ordo-liberal doctrine and fears of moral hazard and the fiscal profligacy of Southern Eurozone member states, which had been kept alive by German political and economic policymaking elites since the creation of the Eurozone (Howarth \& Rommerskirchen, 2013). These arguments were reiterated by Jens Weidmann, the Bundesbank President, in his 2013 hearing before the FCC (Ewing, 2013), which 
incorporated them into its prejudicial question to the CJEU. After the CJEU dismissed these arguments in its final ruling, the FCC expressed its concerns about the lack of both CJEU independent expertise on monetary issues and counter power to the ECB at the EU-level (Gauweiler and Others, 2016). The FCC had laid down the gauntlet on the ECB asset purchase programmes.

The recent Weiss and Others case against the PSPP can be seen as a reaction by a group of German plaintiffs to the CJEU ruling on the Gauweiler case and their failure to rein in ECB sovereign debt bond purchases (Van Der Sluis, 2019). This was a national level fire alarm in reaction to the perceived inadequacies of both EU-level police patrol/fire alarms with regard to the ECB agent. The FCC set the standard of evidence of proportionality very high requiring potentially a full study of the PSPP and proof that its benefits outweighed possible negative effects across any other sector or part of the economy. This is in strong contrast to the jurisprudence of the FCC toward the Bundesbank: The former never ruled a legal case in relation to the monetary policy implemented by the latter (Van Der Sluis, 2019).

The ECB refused to send proof to the FCC that the PSPP complied with the principle of proportionality. Instead, ECB Governing Council members reiterated through press interviews that the ECB was accountable to the European Parliament and subject to the jurisdiction of the CJEU alone (see, for example, Lagarde, 2020). Despite the ECB's defiant response, there is evidence that the ECB sought to avoid future conflict with the FCC. The ECB took unusual steps to demonstrate that its monetary policy decisions and the unconventional instruments they used were compliant with the principle of proportionality pursuant to Article 4 TFEU (Nicolaides, 2020).

First, central bankers referred repeatedly to the proportionality of their asset purchase programmes during the Governing Council meeting of 3-4 June 2020, the first to follow the FCC ruling (Nicolaides, 2020). The summary of this meeting differs significantly from the previous twenty-one summaries of Governing Council meetings, notably in terms of the use of the words 'outweigh/outweighed' and 'proportionality/proportionate/proportional' (Nicolaides, 2020):

Not only does the account refer to the positives outweighing the negatives of PEPP but...it also hedges the position of the ECB in relation to critical issues in the judgment of the FCC, such as the weight that could be attached to the various effects, possible unintended effects of monetary policy, the effectiveness and efficiency of monetary instruments and the impact of low interest rates. (Nicolaides, 2020)

Second, the ECB responded to the FCC ruling by passing previously unpublished documents to the Bundesbank, which then passed them to the German finance minister, Olaf Scholz, who in turn passed them to the president of the Bundestag (Arnold \& Chazan, 2020b). While these documents were not to be made available to the wider public, they were to be examined by the German Ministry of Finance and the Bundestag's Budgetary Committee operating in camera. On 2 July 2020, the Bundestag officially announced that it supported the ECB, having found that the central bank's PSPP was proportional to its price stability objectives (Arnold \& Chazan, 2020c).

The ECB's additional release of information and the modification of the ECB's public justification of its asset purchase programmes are consistent with its overall reputation-building strategy, through which the central bank has tackled public contestation by increasing its communication on controversial issues (Moschella, Pinto, \& Martocchia Diodati, 2020). The ad hoc and informal collaboration of the ECB with the Bundesbank and German political institutions without any formal change to the ECB's accountability either through unilateral ECB official clarification or treaty change can be seen as a 'procedural' type of accountability (Dawson, Maricut-Akbik, \& Bobić, 2019), which weakens the logic of checks and balances within the Eurozone. In terms of principal-agent analysis, this can be labelled as 'buffering' (DiMaggio \& Powell, 1991; Hawkins \& Jacoby, 2006). Buffering involves the provision of information and reporting by the agent in its attempt to satisfy the principals without revealing too much information (Hawkins \& Jacoby, 2006). The label can also be attached to the ECB's largely symbolic engagement efforts with national parliaments (Tesche, 2019). Indeed, the ECB failed to prove that the benefits from its asset purchase programmes outweighed any negative effects in any other sector of the economy because it lacked a model that could aggregate the effects of these programmes in diverse sectors and add them up in any meaningful measure. The ECB was only able to demonstrate that the positive effects exceeded negative effects for a number of specific sectors, including banking. While ECB buffering can be seen as central to the successful resolution of the difficulties created by the FCC ruling, we lack the space in this contribution to examine in full the role of the ECB agent in this context.

In sum, the substance of the arguments mobilized by German public actors and private plaintiffs and, subsequently, by the FCC, shows that they have acted as a national fire alarm in the fear that the ECB was moving too far away from its original monetary policy mandate, based on the Bundesbank (McNamara, 1998). The FCC argument about the lack of counter-power to the ECB at the EU-level also shows that the increased role played by fire alarms at the national level was linked explicitly with the lack of substantive pressure over ECB monetary policy at the EU-level. While the judicialisation of monetary policy by German private plaintiffs forced the ECB to divulge additional documents and provide additional explanations on its asset purchase programmes, it did not trigger adverse moves from either the German political authorities or the Bundesbank, which had vociferously criticised the PSPP since its inception (Braun, 2016; 
Howarth, 2012). Explaining this paradox-specifically the failure of German political and elite economic policymakers to sound the fire alarm in 2020-is likely linked to the severity of the Covid-19-induced macroeconomic crisis in the Eurozone. The aim to avoid a full-blown constitutional crisis in Germany, in which German political authorities would order the politically and operationally independent Bundesbank to withdraw from the Eurosystem of central banks is another potential explanation. Finally, the lack of consistency in the discourse of German elites on ECB monetary policy could be explained by scapegoating tactics, whereby elites score political points at the national level by criticizing ECB policies with ordo-liberal arguments but refrain from assuming the consequences of a German withdrawal from the Eurozone. However, without further empirical research, it would be imprudent to attempt to disentangle these causal explanations: a full explanation of the German politics on the ECB's PSPP must be the subject of another article.

\section{Conclusion}

We return to the research question posed in the introduction to this article: How should we best understand the relationship between the operationally independent ECB and the FCC? We answer this question by arguing that the FCC functions as a fire alarm and in effect a filter for private plaintiffs with the potential to sanction significantly the ECB through rulings on Bundesbank action. We argue that the efforts of German private plaintiffs and the FCC ruling present us with a new understanding of the application of a principal-agent analysis to the operation of the ECB agent and its relationship to its member state principals because the control mechanisms were managed at the national level. Private plaintiffs challenged the ECB for operating in a manner they believed was contrary to its mandate and, specifically, challenged the participation of the Bundesbank in the ECB's PSPP by filing a complaint before the FCC. The FCC pulled the fire alarm by ruling in favour of the private plaintiffs and explicitly requiring the Bundesbank to end its participation in the ECB's PSPP if the latter failed to justify the wider macroeconomic effects of its nonconventional monetary instrument. Both the private plaintiffs and the FCC sought to uphold what they in effect argued and ruled was the correct understanding of the ECB's mandate as agreed by member state heads of government and state in the Maastricht Treaty and inspired in large part by the German central bank and government (Dyson \& Featherstone, 1999). The FCC also intentionally and explicitly sought to highlight the weakness of both EU-level police patrols and fire alarms in relation to the ECB agent and specifically the weakness of the CJEU as a mechanism of control. The indignant response of both the CJEU and the European Commission with regard to the German Constitutional Court's ruling focused principally upon its proclaimed illegality and the assertion of the supremacy of EU law and courts on matters concerning ECB monetary policy. However, the response of the $\mathrm{ECB}$-in passing information to the German government and parliament seeking to demonstrate the macroeconomic proportionality of the PSPP - to avoid a potential constitutional, political and economic crisis shows that the FCC ruling could not be easily ignored.

Stepping aside from the empirical analysis that has driven this article and turning to more normative considerations, we note that the legal and institutional vacuum in which the ECB has operated its nonconventional monetary policy since 2010 can be seen as highly problematic for the balance of powers between the ECB and the other institutions of the EU political system. EU-level ex post controls have been perceived as inadequate. At the same time, we recognise that it is also politically problematic for the FCC to fill the gap by pushing control over the ECB agent to control over the Bundesbank element of that agent. In addition to the legal issues that the FCC's ruling raises, a number of tricky political questions arise. For example, to what extent did the response of the ECB agent reflect the relative economic and political importance of Germany in the Eurozone? Would such a legal challenge in a smaller, less economically and politically important Eurozone country force the ECB to respond in the same way? The unclear answers to these questions raise legitimacy concerns. In the end, the German private plaintiffs did not get their way and the ECB's PSPP was not terminated. However, the ECB's forced response to the FCC ruling combined with the politically timid acceptance of this response by the German government and parliament, sets a clear precedent. The national (German) legal fire alarm highlighted the problematic democratic vacuum in which the ECB operates. A future court case is only a matter of time.

\section{Acknowledgments}

The authors would like to thank the guest editors, the reviewers and Dr. Jakub Gren, an ECB official, for their helpful comments.

\section{Conflict of Interests}

The authors declare no conflict of interests.

\section{References}

Accorinti and Others v. ECB, Case order of the General Court (Fourth Chamber), T-224/12 (2014). Retrieved from http://curia.europa.eu/juris/liste.jsf?num=T224/12\&language $=\mathrm{EN \#}$

Arnold, M. (2020, May 7). Christine Lagarde says ECB is 'undeterred' by German court challenge. Financial Times. Retrieved from https://www.ft.com/content/ d93008c5-2b3c-4b2e-9499-5eabaaa959db

Arnold, M., \& Chazan, G. (2020a, May 8). Germany's ECB critics toast courtroom success. Financial Times. 
Retrieved from https://www.ft.com/content/8a92 ad59-50de-4907-bf65-4086960ac161

Arnold, M., \& Chazan, G. (2020b, June 17). Bundesbank boss moves to diffuse row between ECB and German court. Financial Times. Retrieved from https://www.ft.com/content/7cfabea1-3f18-457aa646-cb0ccf0c1141

Arnold, M., \& Chazan, G. (2020c, July 6). Bundesbank to keep buying bonds after court challenge. Financial Times. Retrieved from https://www.ft.com/content/ 99447f21-46db-465b-8ed0-9a214a898a74

Baroncelli, S. (2016). The Gauweiler judgment in view of the case law of the European Court of Justice on European Central Bank independence: Between substance and form. Maastricht Journal of European and Comparative Law, 23, 79-98.

Berger, H. (2019). How to challenge the ECB: Lessons from first EU court cases on the SSM. Whitecase. Retrieved from https://www.whitecase.com/ publications/insight/financial-regulatory-observerdecember-2019/how-challenge-ecb-lessons

Braun, B. (2016). Speaking to the people? Money, trust, and central bank legitimacy in the age of quantitative easing. Review of International Political Economy, 23(6), 1064-1092.

Chang, M. (2020). Sui generis no more? The ECB's second decade. Journal of European Integration, 42(3), 311-325.

Commission v. ECB, Judgement of the Court, C-11/00, ECLI:EU:C:2003:395 (2003). Retrieved from http:// curia.europa.eu/juris/liste.jsf?language $=e n \& j u r=C$, $\mathrm{T}, \mathrm{F} \&$ num $=\mathrm{C}-11 / 00 \& \mathrm{td}=\mathrm{ALL}$

Court of Auditors. (2019, January 14). European Central Bank must allow full scrutiny of banking supervision, say Auditors [Press Release]. Retrieved from https://www.eca.europa.eu/Lists/News/NEWS1901 _14/INPL19_ECB_EN.pdf

Davies, B. (2012). Resisting the European Court of Justice: West Germany's confrontation with European law, 1949-1979. Cambridge: Cambridge University Press.

Dawson, M., Maricut-Akbik, A., \& Bobić, A. (2019). Reconciling independence and accountability at the European Central Bank: The false promise of proceduralism. European Law Journal, 25, 75-93.

De Cabanes, A., \& Fontan, C. (2019). La cour de justice face à Gauweiler: La mise en récit de l'indépendance de la BCE [The ECJ vs Gauweiler: Narrating the ECB independence]. In A. Bailleux, E. Bernard, \& S. Jacquot (Eds.), Les récits judiciaires de l'Europe [Judicial narratives in Europe] (pp. 169-193). Brussels: Larcier.

Dehousse, R. (2008). Delegation of powers in the European Union: The need for a multi-principals model. West European Politics, 31(4), 789-805.

Delreux, T., \& Adriaensen, J. (2017). The principal agent model and the European Union. Basingstoke: Palgrave.
DiMaggio, P., \& Powell, W. (1991). The new institutionalism in organizational analysis. Chicago, IL: Chicago University Press.

Dutch parliament tells ECB's Draghi it opposes 'tiered' rates. (2019, September 11). Reuters. Retrieved from https://www.reuters.com/article/us-netherlandsecb-rates/dutch-parliament-tells-ecbs-draghi-itopposes-tiered-rates-idUSKCN1VW2GN

Dyson, K. H. F., \& Featherstone, K. (1999). The road to Maastricht: Negotiating Economic and Monetary Union. Oxford: Oxford University Press.

Dyson, K., \& Marcussen, M. (Eds.). (2009). Central banks in the age of the Euro: Europeanization, convergence and power. Oxford: Oxford University Press.

Elgie, R. (2002). The politics of the European central bank: Principal-agent theory and the democratic deficit. Journal of European Public Policy, 9(2), 186-200.

European Central Bank. (2015, January 22). ECB announces expanded asset purchase programme [Press Release]. Retrieved from https://www.ecb. europa.eu/press/pr/date/2015/html/pr150122_ 1.en.html

European Central Bank. (2020, May 5). ECB takes note of German Federal Constitutional Court ruling and remains fully committed to its mandate [Press Release]. Retrieved from https://www.ecb.europa. eu/press/pr/date/2020/html/ecb.pr200505 00a091 07a9.en.html

European Parliament. (2014). Resolution of 13 March 2014 on the enquiry on the role and operations of the Troika (ECB, Commission and IMF) with regard to the Eurozone programme countries (P7_TA(2014)0239). Brussels: European Parliament.

Ewing, J. (2013, June 13). Debate on the Euro's Future in a German Courtroom. The New York Times. Retrieved from https://www.nytimes.com/2013/06/ 12/business/economy/german-court-weighs-bondbuying-by-european-central-bank.html

Fazzini, P., \& Urbani, F. (2020). The ECB that the EU deserves and the one its needs now: Thoughts on the German Constitutional Court's ruling on the public sector purchase programme. Duke University School of Law. Retrieved from https://sites.law.duke.edu/ thefinregblog/2020/06/02/the-ecb-that-the-eudeserves-and-the-one-it-needs-now-thoughts-onthe-german-constitutional-courts-ruling-on-thepublic-sector-purchase-programme

Fontan, C. (2016). Une banque centrale au-dessus des nations? Faire peser les intérêts nationaux au sein de la Banque Centrale Européenne [A central bank above nations? The weight of national interst in the ECB governance]. Revue Française D'administration Publique, 158(2), 491-504.

Frieden, J., \& Walter, S. (2017). Understanding the political economy of the Eurozone crisis. Annual Review of Political Science, 20, 371-390.

Fromage, D., \& Ibrido, R. (2018). The 'banking dialogue' as a model to improve parliamentary involvement in 
the monetary dialogue? Journal of European Integration, 40(3), 295-308.

Gabor, D., \& Ban, C. (2016). Banking on bonds: The new links between states and markets. Journal of Common Market Studies, 54(3), 617-635.

Gandrud, C., \& Hallerberg, M. (2015). Does banking union worsen the EU's democratic deficit? The need for greater supervisory data transparency. Journal of Common Market Studies, 53(4), 769-785.

Gauweiler and Others. (2016). Judgment of the Second Senate of 21 June 2016, 2 BVerfG 2728/13. Retrieved from https://www.bundesverfassungsgericht.de/e/ rs20160621_2bvr272813en.html

Hawkins, D., \& Jacoby, W. (2006). How agentes matter. In D. Hawkins, D. Lake, D. Nielson, \& M. J. Tierney (Eds.), Delegation and agency in international organisations (pp. 199-228). Cambridge: Cambridge University Press.

Hawkins, D., Lake, D., Nielson, D., \& Tierney, M. J. (2006). Delegation under anarchy: States, international organizations, and principal-agent theory. In D. Hawkins, D. Lake, D. Nielson, \& M. J. Tierney (Eds.), Delegation and agency in international organisations (pp. 3-38). Cambridge: Cambridge University Press.

Heldt, E. (2017). Regaining control of errant agents? Agency slack at the European Commission and the World Health Organization. Cooperation and Conflict, 52(4), 469-484.

Högenauer, A. (2019). The politicisation of the European Central Bank and the Bundestag. Politics and Governance, 7(3), 291-302.

Högenauer, A., \& Howarth, D. (2016). Unconventional monetary policy and the European Central Bank's problematic democratic legitimacy. Journal of Public Law, 71(2), 1-24.

Howarth, D. (2012). Unity and disunity among central bankers in an asymmetric Economic and Monetary Union. In J. Hayward \& R. Wurzel (Eds.), European disunion: The multidimensional power struggles ( $\mathrm{pp}$. 131-145). Basingstoke: Palgrave.

Howarth, D., \& Loedel, P. (2005). The European Central Bank: The New European leviathan (2nd ed.). Basingstoke: Palgrave.

Howarth, D., \& Rommerskirchen, C. (2013). A panacea for all times: The politics of the German stability culture. West European Politics, 36(4), 750-770.

Jabko, N. (2001). Expertise et politique à l'âge de l'euro: La Banque centrale européenne sur le terrain de la démocratie [Expertise \& politics in the euro era: The ECB and the democracy]. Revue Française de Science Politique, 51(6), 903-931.

Jabko, N. (2003). Democracy in the age of the euro. Journal of European Public Policy, 10(5), 710-739.

Jabko, N. (2009). Transparency and accountability. In K. Dyson \& M. Marcussen (Eds.), Central banks in the age of the Euro: Europeanization, convergence, and power (pp. 391-406). Oxford: Oxford University Press.
Kiewiet, D. R., \& McCubbins, M. D. (1991). The logic of delegation: Congressional parties and the appropriations process. Chicago, IL: University of Chicago Press.

Lagarde, C. (2020, June 29). Letter to Nuno Melo, MEP (L/CL/20/184). Frankfurt-am-Main: ECB. Retrieved from https://www.ecb.europa.eu/pub/ pdf/other/ecb.mepletter200629_Melo 〜c9f2b38ad6. en.pdf

Majone, G. (2001). Two logics of delegation: Agency and fiduciary relations in EU governance. European Union Politics, 2(1), 103-22.

McCubbins, M., \& Schwartz, T. (1984). Congressional oversight overlooked: Police patrols versus fire alarms. American Journal of Political Science, 28(1), 165-79.

McNamara, K. (1998). The currency of ideas. Ithaca, NY: Cornell University Press.

Mersch, Y. (2020, July 2). In the spirit of European cooperation. European Central Bank. Retrieved from https://www.ecb.europa.eu/press/key/date/2020/ html/ecb.sp200702 87ce377373.en.html

Miller, G. J. (2005). The political evolution of principalagent models. Annual Review of Political Science, 8, 203-225.

Moschella, M., Pinto, L., \& Martocchia Diodati, N. (2020). Let's speak more? How the ECB responds to public contestation. Journal of European Public Policy, 27, 400-418.

Nedergaard, P. (2020). The ordoliberalisation of the European Union? Journal of European Integration, 42(2), 213-230.

Nicolaides, P. (2020, June 29). The ECB is responding to the Federal Constitutional Court of Germany: A comparison of monetary policy accounts. EU Law Live. Retrieved from https://eulawlive.com/op-ed-theecb-is-responding-to-the-federal-constitutionalcourt-of-germany-a-comparison-of-monetarypolicy-accounts-by-phedon-nicolaides

Pollack, M. A. (1997). Delegation, agency and agenda setting in the European Community. International Organization, 51(1) 99-134.

Preliminary references to the Court of Justice of the European Union by constitutional courts [Special issue]. (2015). German Law Journal, 16(6), 1317-1796.

Quaglia, L. (2008). Central banking governance in the European Union: A comparative analysis. London: Routledge.

Rehm, M. (2021). Tug of war over financial assistance: Which way forward for Eurozone stability mechanisms? Politics and Governance, 9(2), 173-184.

Schnabel, I. (2020, June 28). Necessary, suitable and proportionate. Welt am Sonntag. Retrieved from https://www.ecb.europa.eu/press/blog/date/2020/ html/ecb.blog200628 d238a8970c.en.html

Tesche, T. (2019). Instrumentalizing EMU's democratic deficit: The ECB's unconventional accountability measures during the Eurozone crisis. Journal of European Integration, 41, 447-463. 
The German Federal Constitutional Court's PSPP Judgment [Special section]. (2020). German Law Journal, 21(5), 944-1127.

The OMT decision of the German Federal Constitutional Court [Special issue]. (2014). German Law Journal, 15(2), 107-382.

Treaty on the Functioning of the European Union, 2007.

Van Der Sluis, M. (2019). Similar, therefore different: Judicial review of another unconventional monetary policy in Weiss (C-493/17). Legal Issues of Economic Integration, 46(3), 263-284.

Von der Leyen, U. (2020, May 19). Statement by President Von der Leyen. European Commission. Retrieved from https://ec.europa.eu/commission/ presscorner/detail/en/STATEMENT_20_846
Wagstyl, S., \& Jones, C. (2016, April 10). Germany blames Mario Draghi for rise of rightwing AfD party. Financial Times. Retrieved from https://www.ft.com/content/ bc0175c4-ff2b-11e5-9cc4-27926f2b110c

Weiss and Others. (2018). Judgment of the Court (Grand Chamber), C-493/17. Retrieved from http:// curia.europa.eu/juris/liste.jsf?language=en\&num=C493/17

Weiss and Others. (2020). Judgment of the Second Senate, 2 BVerfG 859/15. Retrieved from https://www.bundesverfassungsgericht.de/e/ rs20200505_2bvr085915en.html

Young, B. (2014). German ordoliberalism as agenda setter for the euro crisis: Myth trumps reality. Journal of Contemporary European Studies, 22, 276-287.

\section{About the Authors}

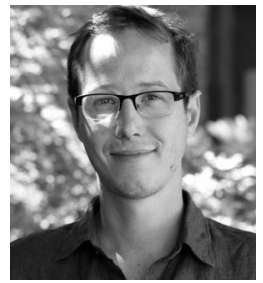

Clément Fontan is Professor of European Economic Policy at the Catholic University of Louvain and University of Saint-Louis Brussels. He is Co-Director of the journal Politique Européenne. He published on central banking and the Eurozone crisis in many scientific journals in French, German and English and he is Co-Author of Do Central Banks Serve the People? (Polity, 2018), translated in French (Raisons d'Agir, 2019) and Korean.

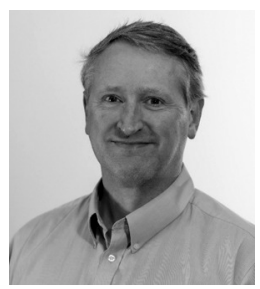

David Howarth is Full Professor in Political Science, European Union Studies and Head of the Robert Schuman Initiative at the University of Luxembourg. He is the Author or Co-Author of four monographs, a textbook, over 90 journal articles and book chapters on European political economy and economic governance topics. He has also edited or co-edited 14 journal special editions and seven books on these topics. Howarth is one of three Editors of the Routledge/UACES series on Contemporary European Studies. 